\title{
ELULOOD JA PÕLVKONDLIKUD MUSTRID
}

\author{
RAILI NUGIN
}

$\mathrm{M}$ uistendid, muinasjutud ning rahvajutud on alati ajas teisenenud: sotsiaalses keskkonnas muudetakse nende rõhuasetusi, lisatakse detaile, pööratakse puänte. Rahvajuttude algupärandid kipuvad ajas kaduma, säilivad vaid need, mida vaevutakse kirja panema. Nii teame, et Charles Perrault' Punamütsike jäigi hundi kõhtu, sest tema ajal oli kombeks rääkida lastele sõnakuulekuse tagamiseks hirmulugusid. Hiljem aga leiti, et laste hirmutamine pole pedagoogiliselt kuigi mõistlik, ning vendade Grimmide versioonis on loole lisandunud jahimehed, kes vaese tüdruku koos vanaemaga kurja hundi kõhust välja lõikavad. Punamütsikese loo üldine jutustusliin on aga seni paika jäänud. Mõned lood teevad seevastu aja jooksul läbi radikaalse muutuse. Nii erines 2010. aastal kinolinal jooksnud Rapuntsli lugu vendade Grimmide versioonist sedavõrd, et ühiseid jooni sellest leida on keerulisemgi kui sarnaseid. Vendade Grimmide vaesest perest pärit Rapuntsel oli filmis röövitud kuningatütar, Grimmide kuningapoeg aga röövel. Kui muinasloos ajas kuri võõrasema vangi tornist välja kõrbe, siis filmis põgenes tütarlaps ise. Selle loeteluga võiks jätkata. Sotsiaalteadlasena huvitavad mind loo autentsuse tagaajamise asemel rõhuasetuste muutumise põhjused, sest need kõnelevad mõndagi ühiskonna laiemalt jagatud väärtuste kohta. Rapuntsli filmis muutub tüdruk, kes võõrasema sõna kuulab (printsi tuppa laskmine toimub siiras usus, et see on lubatud, ning Rapuntsel lobiseb oma vangishoidjale ise troonipärija külaskäikudest), söakaks ja mässuliseks tegelaskujuks, kes ei vannu ühelegi ohule alla ning haarab saatuse kujundamise ohjad enda kätte. Grimmide versiooni Rapuntsel laseb end aga häbihüüete saatel kõrbe kihutada ning oskab seal end vaid haletseda. Kuningapoeg (kelle silmad kuri nõid välja torkab) leiab oma armastatu pelgalt tänu juhusele, sest kummalegi armunule ei tule pähegi, et nad saaksid või võiksid oma saatust ise muuta.

Teisisõnu, peamiselt on muutunud tegelaskujude a g e $\mathrm{n} t \mathrm{~s}$ u s. Sotsioloogia algusaegadest peale on vaieldud agentsuse ja struktuuri omavaheliste suhete üle. Kui suurel määral sõltub inimese käekäik teda ümbritsevast sotsiaalsest struktuurist (sotsiaalne ja geograafiline päritolu, ühiskonnakorraldus, poliitiline süsteem jne) ning mil määral on tal enesel võimalik muuta oma sotsiaalset positsiooni või mõjutada karjääri? Mil moel mõjutavad turbulentsed muutused indiviidide elukäiku ja kas nende käigus on inimese enda roll määravam kui teda ümbritsevatel muutustel? Sarnaste kana/muna-tüüpi küsimuste üle murtakse pead juba aastasadu. Käesoleva kirjutise küsimusepüstitus on aga veidi teistsugune: püüan uurida mitte sedavõrd indiviidi rolli omaenda elukäigu kujundamisel, vaid eelkõige seda, kuidas sellest jutustatakse. Mismoodi kõnelevad oma elu-/edulugudest need, kes elasid muutuste keerises ning kellel õnnestus noores eas hõivata mõjukaid ametikohti, nautides ülenevat sotsiaalset mobiilsust? Täpsemalt analüüsin artiklis 1970. aastatel sündinud eagrupi kvalitatiivsetes intervjuudes (eluloolised, fookusgrupi ja 
süvaintervjuud) mulle jutustatud lugusid ning vaatan, kuidas neis räägitakse iseenda rollist ehk agentsusest ning mil määral omistatakse oma elukäigus toimunud arengule ühiskondlikke põhjuseid (ehk viidatakse sotsiaalsele struktuurile). Rapuntsli loo näide polnud juhuslik: tänases lääne individualiseerunud ühiskonnas rõhutatakse indiviidi rolli ja vastutust rohkem kui eelnevatel ajastutel. Enamik Hollywoodi linateoseid kirjeldab mõnd edulugu oma õnne eest võitlevast protagonistist, kes ei vannu saatusele alla ning saavutab oma soovitu (Twenge 2006). Ka liberalistlik poliitfilosoofia rõhutab üksikisiku rolli edu saavutamisel ning sellekohaselt on sotsiaalselt vähem privilegeeritud oma ebaõnnes ise süüdi. See omakorda võiks tähendada sedagi, et indiviid kirjeldab oma saavutusi rangelt individualistlikus võtmes ka siis, kui edulugu oli juhuslik või õnn niisama sülle pudenes. Näiteks võiks Grimmi kuningapoeg suurustada, et otsis süstemaatiliselt südamedaami ega hoolinud oma pimedusest, poetamata sõnagi sellest, et tegelikult leidis ta Rapuntsli tänu õnnelikule juhusele.

Käesolev artikkel panustab viimastel kümnenditel nii Eestis kui ka mujal maailmas kanda kinnitanud mälu-uuringutesse. Mäletamispraktikate uurimise kasv on osaliselt aset leidnud tänu võimalusele uuesti nähtavale tuua inimeste erinevad saatused, mida külma sõja ajal varjama pidi. Teisalt on mälu-uuringute tõus seotud suuresti globaalsete ühiskondlike arengutega, mille käigus individuaalne lugu, isikupära ja identiteediotsingud on saavutanud keskse tähtsuse (Bauman 1998). Eestis on mälu-uuringuteks viljaka pinnase loonud nii Eesti Kirjandusmuuseumi elulookogumise kampaaniad, Eesti Rahva Muuseumi välitööd ning erinevad küsitluslehed kui ka Eesti Elulugude Ühenduse tegevus. Elulugusid on uuritud nii kirjandusloolisest, (suulise) ajaloo kui ka etnoloogilisest perspektiivist (vt lähemalt Hinrikus 2003; Kõresaar, Jõesalu 2016). Järjest enam on levinud kvalitatiivsete elulooliste intervjuude kasutamine sotsiaalteadustes (vt Aarelaid-Tart 2006; Grishakova, Kazjulja 2008; Saar, Kazjulja 2016). Käesoleva artikli lähenemissuund on peamiselt sotsioloogiline, sest seab uurimisfookusse ühiskonna ning indiviidi suhte.

\section{Valim ja meetodid}

Lood, mida ma eelnimetatud küsimusepüstitusest lähtuvalt analüüsin, on kogutud enam kui kümme aastat kestnud uurimistöö käigus. Intervjuusid kogusin kuues peamises uuringufaasis, vesteldes kokku 47 inimesega, kes olid sündinud ajavahemikus 1970-1978. Peamine informantide valiku kriteerium oligi nende sünniaasta. Mulle pakkus huvi just see vanusegrupp, sest nemad olid sündinud nõukogude perioodil ning nende teismeiga möödus ajal, mil Eesti oli suurte ühiskondlike ja poliitiliste muutuste lävepakul. Nad ei olnud muudatuste eesotsas, ent olid piisavalt vanad, et toimuva vastu huvi tunda ning selle ulatust ja tähendust mõista (või aimata). Murrangulised protsessid toimusid just siis, kui see eagrupp jõudis oma elus punkti, mil nad pidid hakkama tegema tulevikku kujundavaid otsuseid: mida õppida, kuhu minna tööle, millal luua pere. Samal ajal olid arusaamad ja võimalused nendest otsustest muutumas: uued õppeprogrammid ja koolid olid tekkimas (ja vanad kadumas), kujunesid uued ametid, ettevõtted, demograafiline käitumine ja arusaamad pere loomisest ja laste saamisest muutusid. Tahtsin teada, kuidas nad oma elukäiku kirjeldavad ning millise rolli omistavad oma elus ühiskondlikele muutustele (detailsema pildi saamiseks vt intervjueeritavate tabelit $\mathrm{nr} 1$ ). 
Informantide kirjeldus

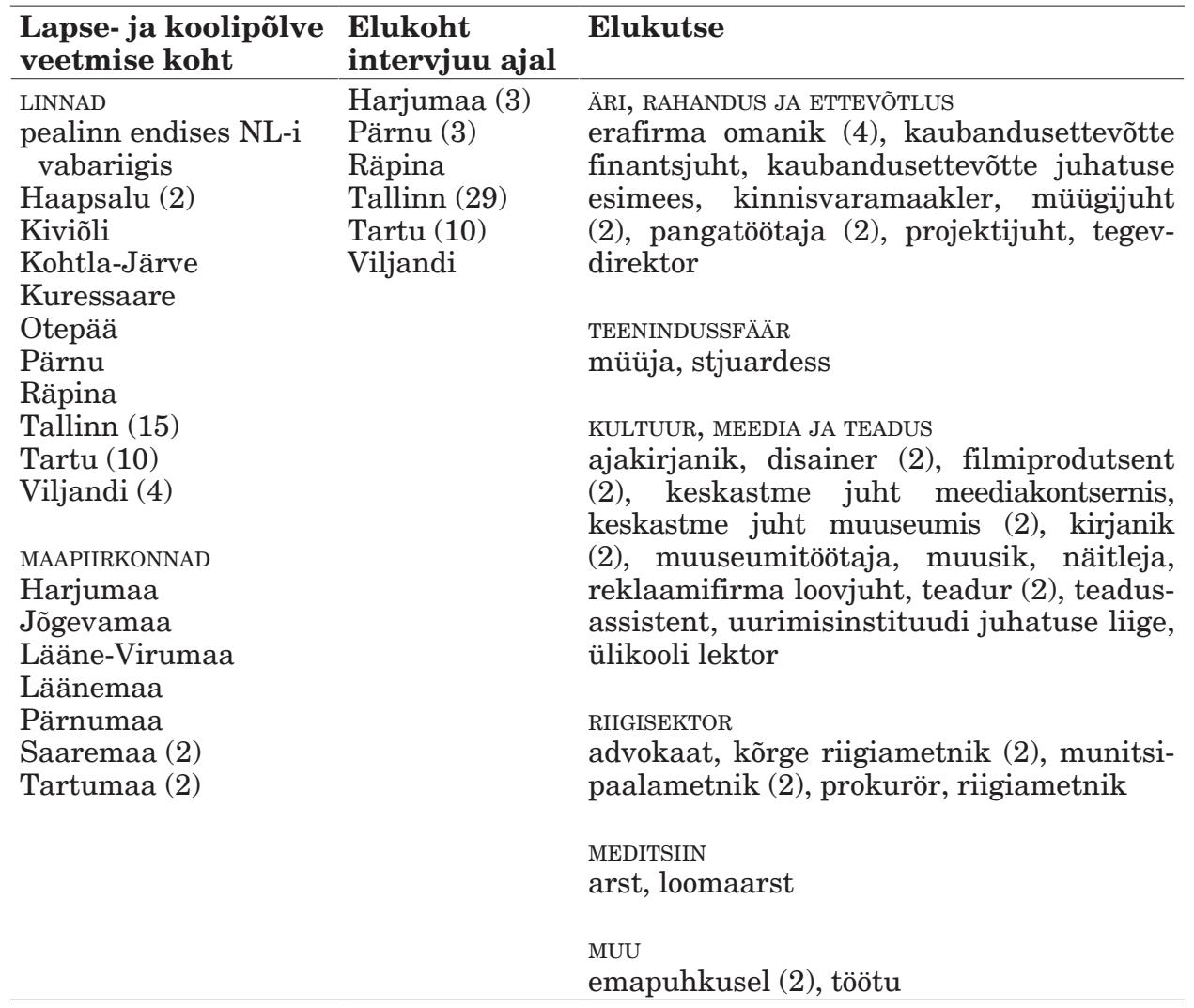

Lisaks vanusele oli kriteeriumiks asjaolu, et informandid oleksid ühel või teisel moel ühiskonnas kuuldavad. See ei tähenda ilmtingimata, et nad oleksid arvamusliidrid või tuntud meediategelased, pigem seda, et nad on oma tegevusväljal saavutanud piisavalt sümbolilist, kultuurilist, sotsiaalset või majanduslikku kapitali (defineerituna Bourdieu ja Wacquanti 2005 järgi) ning tunnevad ühiskondlike protsesside vastu huvi. Seega oli lähenemine peamiselt eliidikeskne, sest soovisin uurida nn dominantseid narratiive. Viimaste all pean silmas neid jutustusi, mis leiavad tee peavoolumeediasse, kujundades suure osa meediatarbijate arusaamu. Samas ei pea nende jutustuste loojad ilmtingimata ise ajakirjanduse veergudel neid arvamusi esitama. Pigem tähendab see, et neil on teatud autoriteet (sümboliline kapital) nendel väljadel, millel nad ise toimetavad - olgu see siis meedia, kultuur, meditsiin või õigus; oskus veenvalt oma refleksiivseid mõtteid sõnastada (kultuuriline kapital) või lai tutvusringkond, kelle hulgas neid lugusid rääkida (sotsiaalne kapital). Sellised nn narratiivid või jutustusvormid kujunevad välja kollektiivselt: indiviidid kasutavad jutustamisel neid narratiivseid mustreid, mida nad ise kuulnud on ja mis neile kõige sümpaatsemad tunduvad, lisades neile teatud aktsente (Harbus 2011: 207, 209). Nii muutub ajapikku ringluses olles jutustuste toon ja muster (Stur- 
ken 2008: 74). Kõige populaarsemad neist domineerivad ka peavoolumeedias ning sotsiaalmeedias, kujundades seeläbi avalikku arvamust.

Kuigi valim oli üsna homogeenne, püüdsin siiski leida erinevate elualade ja erineva geograafilise päritoluga informante, et andmed oleksid kõnekamad ja illustreeriksid võimalikult laia paletti eliidist. Kuigi suurem osa intervjueeritavatest elab praegu Eesti suuremates linnades (peamiselt Tartus või Tallinnas), üritasin leida Eesti eri paikades lapsepõlve veetnud inimesi. Nii on esindatud seitsme maakonna elanikud erinevatest asulatüüpidest (nii linnad, asulad kui ka külad). Vestlesin nii äri- kui ka pangandusmaailma esindajatega, juriidilises sfääris töötajatega, riigiasutuste kõrgemate ametnikega, muuseumitöötajatega, kunstnike ja teiste loovate elualade esindajatega, ajakirjanike ja teadlastega. Valim on sooliselt tasakaalus, informantide nimed on tekstis vastajate anonüümsuse huvides muudetud.

Oma uuringu alguses keskendusin peamiselt temaatilistele süvaintervjuudele, mille keskmes oli informandi elu keskkooli lõpetamise ajal, tema valikute tagamaad, elukäik ja suhtumine muutustesse. Teises staadiumis lisandus intervjuudele rõhuasetus põlvkondlikule kuuluvusele ning selle piiridel. Kolmandas staadiumis viisin läbi fookusgrupi intervjuusid, ${ }^{1}$ mille kese lasus põlvkondlike piiride määratlemisel ning selle põhjendustel. Edasistes etappides viisin läbi peamiselt eluloolisi intervjuusid, neist kuus koos etnoloog Kirsti Jõesaluga (millest omakorda kaks olid grupiintervjuud). ${ }^{2}$ Intervjuud kestsid tunnist kahe tunnini. Intervjuud salvestati, transkribeeriti ning analüüsiti käesoleva artikli jaoks kvalitatiivse sisuanalüüsi meetodit kasutades. Selle meetodi käigus sõnastatakse teemad, mis uurijale huvi pakuvad. Käesoleva artikli raames huvitas mind jutustuse tonaalsus ja mina-roll ning viited ühiskonna osakaalule eluloos. Järgmises etapis kodeeritakse intervjuu sisu. Intervjuu osadele antakse nimetus ehk kood, mis kirjeldab intervjueeritava mõtet uurimisküsimusest lähtuvalt: jutustuse tonaalsus ja mina-rolli rõhutamine (või sellest hoidumine) ning viited ühiskonna rollile eluloos. Kood annab vastuse sellele, kuidas vastaval teemal räägitakse. Seejärel grupeeritakse sarnaseid mõtteid kajastavad koodid suuremate kategooriate alla, aidates nii teemadele struktuurselt läheneda.

\section{Sotsiaalne struktuur}

Enne kui asuda informantide jutustuste avamise juurde, pean vajalikuks rääkida põgusalt n-ö struktuurist ehk valimit ümbritsenud sotsiaalsetest tingimustest. Püüan näidata, kuivõrd soosis ühiskondlik raamistik selle eagrupi edu tööturul ja millised haridusmaastiku muudatused võisid nende eluteevalikuid mõjutada.

Enamik intervjueeritavatest käis ühiskondlike muutuste alguses koolis (sõltuvalt sünniaastast kas algklassides või keskkoolis) ning seega mõjutasid neid kõiki ka ümberkorraldused hariduses, mis said nii mõneski koolis alguse juba nõukogude võimu lõpus: koolivormi kaotamine, õppekava paindlikumaks

\footnotetext{
${ }^{1}$ Ühe fookusgrupi intervjuu viis läbi Kirsti Jõesalu, kes osales koos minuga ka ühes teises fookusgrupi intervjuus.

${ }^{2}$ Kuna koos Kirsti Jõesaluga tehtud intervjuude informantideks olid kultuuritekstide loojad, keskendusime neis intervjuudes ka kultuuritekstide loomise tagamaadele (vt Jõesalu, Nugin 2012; Nugin, Jõesalu 2016).
} 
tegemine, programmi sisu muutmine. Lisaks muutus haridusasutuste struktuur. Üldises detsentraliseerimise ja liberaliseerimise tuhinas jätsid mõned muutused suisa kaootilise mulje. Võis juhtuda sedagi, et see, mis ühele lennule/kohordile oli lubatud, järgmisele keelati ning vastupidi. 1990. aastatel toimus kõrghariduse nn ekspansioon (nagu oli omane ka teistele postsotsialistlikele riikidele, vt Kogan, Unt 2005: 226), mis esmalt avaldus plahvatuslikus kõrgkoolide arvu kasvus. Esimese iseseisvuskümnendiga (2001. aastaks) kasvas kõrgemat haridust pakkuvate asutuste arv viiekümneni, mis Eestisuuruse riigi kohta on üsna suur arv. ${ }^{3}$ Lisaks sellele suurendasid vastuvõttu olemasolevad riiklikud ülikoolid, mis said uue korralduse tõttu kaasata tudengeid, kes oma hariduse eest maksid. Seega paisus jõuliselt kõrgkooli astunute arv, kasvades aastatel 1990-2000 $223 \%$. On huvitav märkida, et kõrgkooli lõpetanute arv jäi esialgu üldjoontes samaks, sest paljud sisseastunud venitasid õpingud pikaks või ei lõpetanud kooli. Paradoksaalsel kombel pole kõrghariduse ekspansioonist osa saanud 1970. aastate kohort tingimata kõrgemalt haritud kui neist vanemad kohordid või kui, siis ainult need, kes sündisid kümnendi lõpus.

Kõrgkooli poolelijätmine või õpingute pikalevenimine tulenes sageli sellest, et see kohort alustas massiliselt töötamist ülikooliõpingute kõrvalt. Mitmed neist asusid tööle ametites, mis tänasele kõrgkoolis õppijale tunduvad kättesaamatuna: õpingute kõrvalt töötati ministeeriumides, pankades ja eraettevõtete juhtivkohtadel. Selle eagrupi esindatus taolistes ametites oli nii silmapaistev, et Eesti Ekspressis ilmus artikkel, kus selle esindajaid kutsuti pintsaklipslaste põlvkonnaks (Funk jt 1995). See silt tähistas noori ja edukaid karjäärile keskendunud mehi ning leidis põgusalt laiemat kasutust avalikus diskursuses. Mõistagi polnud kõigi samal ajal sündinute käekäik samasugune (nagu nimetuski viitab, paistsid kõrgetel positsioonidel silma peamiselt mehed), ent ülenev mobiilsus iseloomustab seda eagruppi rohkem kui teisi. Koguni 40-45\% aastatel 1992-2005 koolist tööturule siirdunutest asusid ametisse kõrgema või keskastme spetsialistidena (Toomse 2004). Samuti on nende töötuse protsent madalam kui hiljem tööturule sisenejatel ning nende sissetulekud tõusid majanduskasvu ajal võrreldes teiste eagruppidega proportsionaalselt rohkem. 2005. aastal läbiviidud uuringu kohaselt väitsid aastatel 1969-1973 sündinutest 47,2 \% ning 1974-1978 sündinutest 49,5\%, et on oma sissetulekuga „väga rahul” (Katus jt 2008), samal ajal kui nii vanemate kui ka nooremate kohortide seas olid need osakaalud väiksemad (vanematel 43,3\% ning noorematel 46,9\%).

Kokkuvõtvalt võib öelda, et 1970. aastatel sündinud said täiskasvanuks ajal, mil sotsiaalne struktuur oli nende arengu seisukohalt soodne - vähemasti tööturu ja sissetuleku mõttes. Kindlasti tuleb aga arvestada asjaolu, et 1990. algusaastate märksõnade hulka kuuluvad majanduslangus, kütusekriis, isegi talongid. Senine plaanimajandusel püsinud majandusstruktuur kukkus kokku, hinnad ning kaubavahetusregulatsioonid lasti vabaks ning endine Nõukogude Liidu turg peamise ekspordisihtkohana kadus. Nende arengute tõttu langes 1992. aastal SKP $22 \%$ ning tarbekaupade inflatsioon tõusis 1069 \% (Saar, Unt 2008). Samasse aega jäävad kriminaalse maailma hiilgeajad, mil vargused ja tapmised olid igapäevased. Seega on 1970. aastatel sündinute edukuse mündil ka teine pool: 1990. aastate majandus-

${ }^{3}$ Siin ja edaspidi on kasutatud Statistikaameti andmeid, kui ei ole viidatud teisiti. 
keskkond võis soosida ülenevat mobiilsust, ent oli sellegipoolest hektiline, rahapuudus oli igapäevane ning elementaarsete tarbekaupade muretsemine võis osutuda keeruliseks, öistel tänavatel liikumine oli ohtlik ning varguse ohvriks langemine polnud ebatavaline.

\section{Jutustatud lood}

Nagu öeldud, huvitab mind käesolevas artiklis jutustuste alatoon või neis esinevad mustrid. James Wertsch (2002) on öelnud, et igal narratiivil on oma sisemine struktuur, muster või šabloon (ingl narrative template) ja see on sügavalt kultuurikeskne. Wertschi järgi tähendab muster seda, et kultuuriliselt on lugudes teatud stereotüüpsed rollid: kuri nõid, tagakiusatud noorim kuningapoeg, kes osutub nutikaks, tagasihoidlik sõnakuulelik talutütar, kes abiellub printsiga jne. Sündmuste käik võib kõigis lugudes erineda, ent rollijaotused püsivad samana. Kuigi Wertsch kasutas ise teooriat erinevate kultuuride ajalookäsitluse uurimiseks, võib seda kasutada ka näiteks erinevate eagruppide narratiivide analüüsiks. Mõistagi on need šabloonid ajas muutuvad, kuid võimalik, et ühe perioodi lugusid räägitakse ühes eagrupis sarnaselt. Ka Antonina Harbus (2011) on rõhutanud, et elulugude jutustamisel/kirjutamisel kasutatakse kindlaid kultuurikeskseid skeeme, mis määravad, kuidas kujutatakse jutustuses põhjuslikke ning ajalisi seoseid, suhteid institutsioonidega ning nende rolli isiksuse arengus. Ka see, mida peetakse mäletamisväärseks ning millised tõlgendamisvõimalused on ühel või teisel lool, sõltub sellest, millised on kollektiivselt jagatud arusaamad (Harbus 2011: 212; Corsten 1999).

Minu eesmärk ongi vaadata, millised on intervjuude narratiivsed mustrid. Uurin ka, kuivõrd vastajad viitavad elulugudes omaenda agentsusele ning mil määral viitavad oma elu keerdkäike põhjendades ühiskondlikele muudatustele. Pööran tähelepanu nende valikute kaalutlustele, samuti sellele, millise tähenduse nad sellele ajale üldiselt annavad. Aja kujutamine jutustustes on oluline ka agentsuse seisukohalt: see, milliste rõhuasetustega räägitakse ajastust, mõjutab paljuski iseenda rolli nägemist selles.

Kaduvad pidepunktid ja kiiresti muutuv ühiskond. Kui noor inimene asub oma valikuid langetama, otsib ta eeskujusid ümbritsevast ühiskonnast. 1970. aastate alguses sündinute jaoks pärinesid rollimudelid otsuste tegemise ajal ühiskonnast, mis mõne aastaga drastiliselt muutus. Nii kirjeldas oma 1987. aastal tehtud valikut pärast põhikooli kutsekooli kokaks õppima minna Mart (snd 1972):

...noh selles mõttes ma võin nagu öelda, et see kaubandustehnikum, mis tundus võib-olla kaheksanda klassi lõpetamisel väga tore idee, et voh, milline salamaailm, et restoranid ja baarid, kuhu ju ei saanud ei sisse... et vähe sellest, et sinna nagu ise ei saanud, et nagu üldse keegi ei saanud... et nihuke tore uksehoidja oli seal ees, kes nagu hoidis pooltühja saali... mõtled, et siis nagu kuulud mingisugusesse salamaailma praktiliselt eksole... Et... et... noh, hilisema järelemõtlemise tulemusena ei olnud see otsus võib-olla kõige õigem, et ega see tehnikum peale keskhariduse suurt midagi ei ole andnud eksole. 
Ei saa muidugi välistada, et Mart oleks oma valikut kahetsenud ka siis, kui ühiskond poleks muutunud: 15-aastaselt tehtud eelistused võivad muutuda mis tahes riigikorra puhul. Ent konkreetsel juhul on märkimisväärne, et terve Mardi kirjeldatud restoranisüsteem ja -korraldus ning nende sümboolne tähendus ühiskonnas muutus drastiliselt. Ajastul, millele informant viitab, oli (teatud) restoranidele ligipääs keeruline ning järjekorrad restoranide uste taga olid tavapärased. Järjekordi haldasid kõrge sotsiaalse ja sümboolse staatusega portjeed, kes lasid inimesi sisse pahatihti oma suva järgi (sh väljaspool järjekorda). Seega oli tutvus mõne restoranis töötava inimesega ihaldusväärne sotsiaalne kapital. Ehkki restoranid kui toitlustusasutused pole kadunud ning ka kokkade ametikoht on olemas, on nendele omistatud tähendus sümboolses hierarhias muutunud.

Kui Mart kirjeldas oma põhikooli lõpus (1987) tehtud otsust, siis näiteks Riina (snd 1973) rääkis segadusest ja sellega seonduvatest hirmudest keskkooli lõpus (1992):

See [mida oma tulevikuga teha $-R$. N.] tegi mulle tõsist muret. Küll aga ma teadsin, et, et ma... et kui ma näiteks teen mingit tööd praegu selleks, et ülikoolis raha saada, siis ma käisin õmblemas. Sest ma teadsin kogu aeg, et see on nagu ajutine asi. Eeskujudest oli mul nii palju, et mul oli ema raamatupidaja, siis ma nagu teadsin, et raamatupidamine on väga keeruline. Aga ma õppisin ka raamatupidamise selgeks... Nii et mul oli kõik planeeritud. Seda ma tegin ülikooli kõrvalt. Igaks juhuks, see on nagu see mure, et sa pead millegagi reaalselt raha teenima. Noh, nagu õpid õpetajaks. Vaata, see on see, et sul ei ole korralikke eeskujusid. Mida ma olin näinud, oli ema töökoht ja õpetajad. Nii et mind kutsuti tegelikult... Mul oli nagu selline plaan, et kui ma saan matemaatika õpetajaks, siis ma lähen X kooli, sest ma ei olnud näinud muid asju... Mulle tundus, et kooliõpetaja ametil pole ju nagu viga midagi, et suvi on vaba ja vaheajad on pikad ja poolest päevast saad koju ja põhimõtteliselt õpetaja... klassijuhataja arvas, et must saaks väga hea õpetaja. Aga... kui ma siis juba Pedas olin, siis ma sain küll aru, et... Et okei, ma võin selle kõik ära õppida - kahendsüsteem ja kaheksandsüsteem ja kõik - aga keegi on selle välja mõelnud. Ja ma ei saa kunagi aru inimestest, kes on selle välja mõelnud. See oli see viga.

Riina näide illustreerib, et ka tema otsis rollimudeleid, ent oli segaduses, millist valida. Asjaolu, et tema segadus tulenes ühiskonnakorra muutusest, on spekulatsioon, sest mõistagi pole selline peataolek mis tahes ajal harv nähe keskkoolilõpetajate seas. Ometi ei lõpetanud ei Mart ega Riina oma valitud eriala. Mart ei läinud kõrgkooli kohe pärast keskkooli lõpetamist, vaid töötas erinevatel ametikohtadel, kuni otsustas minna kunstiülikooli disaini õppima. Selle lõpetanuna ei leidnud ta ka disaineri elukutses oma tõelist kutset, vaid töötas erinevatel turundustöökohtadel ja IT-valdkonnas. Riina katkestas matemaatikaõpingud ning asutas turundusfirma, õppis juurat ning ajalugu ja on osalenud aktiivselt ühiskondlikus elus. Nende hektiline karjäär polegi siinkohal nii oluline (kuigi see on iseloomulik paljudele selle kohordi esindajatele), pigem on märkimist väärt asjaolu, et kummagi ametikohta, positsiooni ega eluala polnud valikute langetamise hetkel sellisel kujul olemas. Teisisõnu kumab mõlema jutust läbi, et nad tegid oma valikud olukorras, kus meelepäraseid eeskujusid polnud ja olemasolevad olid muutumises. 
Karmist korrast kaoseni. Et poliitilised muutused toimusid kiiresti, võivad keskkooliperioodi kirjeldused erineda sõltuvalt sünniaastast ning 1970. aastate alguses sündinute lugudes võib sagedamini kuulda repressioonide hirmust:

Kati (snd 1970): Olin abituuriumis 87-88. Pole hiljem mõelnud selle peale, aga teatud osa ajast tundsin ennast laulva revolutsiooni põlvkonnana. Hirvepargis ma ei käinud, aga klassijuhataja käis ja rääkis. Fosforiidikevade $87 \ldots$ 10. klassi lõpu ajal oli midagi kevadel tunda. Keskkooli viimases klassis oli meil paar noort õpetajat - ajalugu ja kirjandus. Ja me kirjanduse õpetaja niiöelda vabanemise intuitiivses tajus... et NL kukub kokku, et meile omavoliliselt jättis võtmata teatud osa programmist ja sellest, mis oli ette nähtud, me lugesime ainult „Hamletit” ja „Fausti”. Ja siis hakkas ta rääkima meile Piibli müüte. Me konspekteerisime tunnis. Detsembri alguses käis KGB ja ta pandi hullumajja kinnisesse osakonda. Ja siis tuli pensionile läinud õpetaja tagasi. Käis erkrohelise krimpleenkleidiga ja tindiga lillaks värvitud juustega. Siis tuli „Vaikne Don” ja „Ülesküntud uudismaa”.

Kati lisas, et koolidirektor oli helistanud ta emale ning ähvardanud ka Katit hullumaja ning koguni Siberisse saatmisega, kui viimane kirjandusõpetajaga peaks suhtlema. Kati tsitaat tundub liialdatud. Goethe kuulus ka nõukogude ajal kooliprogrammi, 1987. aastal ei saadetud enam kedagi Siberisse ning õppeprogrammi eiramise eest võidi halvimal juhul ehk koolist vallandada. Minu jaoks on Kati jutus oluline muu. Ta mäletab ja soovib edasi anda seda hirmu ja segadust, mida ta keskkooli lõpuklassis tundis. Nagu ta isegi viitab, tunneb ta selliste läbielamiste tõttu end „revolutsiooni põlvkonnana”, sest õhus oli intuitiivselt võimalik tajuda vabanemist, ent teisalt valitses süsteemi siiski raudne haare, mis reaalselt inimesi hirmutas.

Lugusid reaalsest hirmust jutustasid ka Janek (snd 1971) ja Hannes (snd 1973), rääkides oma põgenemistest kohustusliku Nõukogude sõjaväeteenistuse eest. Janek pääses teenistusest tänu ema tutvustele. Ta teeskles pimesoolepõletikku ning pidi läbi tegema pimesoole eemaldamise operatsiooni. Hannesel läks mõnevõrra kergemini:

V: Ma mäletan seda, et meil oli üks hetk, kus [---] meile teatud inimesed helistasid läbi... ja ütlesid, et poisid, pange nüüd metsa. Ma mõtlesin, et mis mõttes metsa, ta ütles, et muidu lähete Afganistani kohe [---] See oli enne nüüd, kui siis ametlikult asi läbi sai, kui oli see viimane agoonia... kui siis öeldi, et noh põhimõtteliselt minge kodust ära paariks päevaks... noh eks me siis läksime.

K: Ja käidi siis kodus ka?

V: Ei käidud, aga ma ei tea, miks, [---] see kes helistas, et tal oli... noh teda tasus nagu selles mõttes kuulata, [---] ta teadis tegelikult, millest ta nagu räägib... ja ja ju siis oli plaan, aga no ju see plaan siis mingi hetk võib-olla või siis nad juba said aru, et see on lootusetu juba...

Seega kumas nende juttudest läbi hirm, mis aga järgmisel hetkel (ja veel enam tagantjärele) tundus juba absurdne. Piiripealne olek ja taju „limbos” veedetud ajast kõlab ka nende jutustustes, kes olid sündinud mõni aasta hiljem. Erinevalt Kati kujutatud karmide reeglitega maailmast oli nii mõnegi 
noorema vastaja loodud pilt paradoksaalsel kombel vastupidine. Marko (snd 1974) võrdles keskkooliaega ajastuga, mida Erich Maria Remarque oma raamatutes on kirjeldanud: „...kõik laguneb ja kaob.” Sama fenomeni pidas silmas ka Tarmo (snd 1976), viidates sellest perioodist kõneledes Hemingway teostele ja tema kadunud põlvkonnale. Mõned 1990. aastate alguses keskkoolipõlve veetnud vastajad läksid kaugemalegi:

Henri (snd 1975): Ei, aga mõtle, keskkooli ajal, kas oleks nagu võimalik, me käisime näiteks keskkooli ajal Eeslitallis ja jõime kokkuleppel baaridaamiga seal alkoholi eksju. Praegust see pole enam võimalik ju. Sa saad ju trahvid ja kõik mis asjad eksju kaela.

Meelis (snd 1973): Seda küll jah.

H: Asi on läinud tunduvalt nagu korrastatumaks eksju. Ja nõukogude ajal polnud see ammugi enam võimalik eksju. Et see oli ikkagi mingisugune aeg, kus sul nagu

M: Vabadus oli üle igasuguste piiride...

H: Täpselt...

Kati, Janeki ja Hannese keskkooliaega lahutasid Henri, Meelise, Tarmo ja Marko omast vaid mõned aastad. Ja ehkki nende rõhuasetused on jutustustes erinevad - ühed kirjeldavad hirmu karistuste ees ning teised karistamatust -, ühendab siiski nende lugusid ajastu taju. Nad tunnetavad seda aega ühelt poolt murrangulisena, teisalt vahepealsena.

Lõbus segadus. Täiskasvanuks saamine ei toimu üleöö. Elus on küll teatud verstapostid ja eri ühiskondades erinevad rituaalid selle tähistamiseks, ent paratamatult jääb lapsepõlve ja täiskasvanuperioodi vahele teatud eneseotsingute aeg, mil inimese staatus on ebakindel. Antropoloogias kasutatakse selle eluperioodi kohta mõistet liminaalne ebakindlus (Gennep 1960; Turner 1969). Minu informantide seas langes see liminaalne ebakindlusperiood kokku ajastuga, mil neid ümbritsev ühiskond läbis samasugust perioodi. Seetõttu pole imestamisväärne, et nende loodud ajapildis on omajagu ebakindlust ja segadust. Teadmatus muutuste suuna osas võib tekitada kõhedust tuleviku ees, ent see hirm ei paista kuigivõrd välja narratiivist. Kindlasti on hirmu puudumise üks põhjustest asjaolu, et oma elust räägiti mulle tagantjärele ning juba positsioonil, mil teatud rahulolupunkt elus oli saavutatud, mistõttu vaadeldi ka ajastut retrospektiivselt. Teisisõnu, ehkki majanduslikke kitsaskohti mainiti, ei olnud need valdavad ning kõlama jäi pigem positiivsus.

Kristi (snd 1974): See oli... see oli rubla lõpp. Väga lõbus aeg oli.

Mart (snd 1972): ja ... see oli päris pull aeg... saada ei olnud midagi, aga kõike sai teha...

Peeter (snd 1974): me sattusime elama huvitaval ajal eksju... või keskkoolis käima huvitaval ajal...

Kui käesoleva ühiskonnakorraldusega ollakse rahul, hinnatakse ka muutusi enamasti positiivsena, isegi kui nende läbielamine tähendab majanduslikku virelemist või raskusi (vt ka Vogt 2005). Tähelepanu väärib siinjuures seik, et kõigi jutust võib aimata teatavat kõrvalseisja pilku, mis kõige paremini 
on sõnastatud Peetri väljendis „sattusime elama”. Muutuste kõrghetkel olid informandid liiga noored, et ise nende eesotsas olla, seega on arusaadav, et toimuvat hinnati kõrvalt. Selline jutustamisstrateegia tuleneb ilmselt sellestki, et paljud neist ei osanud muretseda oma tuleviku pärast, kuid ei pidanud väga pead murdma ka oleviku (eluaseme või toidu) pärast, kuna elasid vanemate juures. Lisaks sellele olid nad oma elutee kujundamisel alles stardipakkudel ning ei pidanud muutuste tõttu oma elu ümber orienteerima. Peeter rääkis, et saab alles tagantjärele aru, milliste dilemmade ees olid pöördehetkedel ta vanemad (,sisuliselt nende elu keerati nagu pea peale”) ning et ta oli nende suhtes tollal ülekohtune. Ta meenutas, et pidas neid siis argadeks, kuna nad muretsesid argiste asjade pärast (,ja nad ikka mõtlesid, et peaks ostma nagu makarone ja asju ja niimoodi..."), selle asemel et rõõmustada positiivsete poliitiliste muutuste üle ühiskonnas. Ka Riina, kes elas juba keskkooli ajal üksi ja pidi peamiselt ise leiva lauale otsima, väljendas arusaamatust selle üle, miks inimesed muretsesid: „Aga noh, see sihukene vanemate erutus, et ei tea, mis nüüd saab... Mis siis saab?" Riina sõnul pidas tema kogu muutusteprotsessi normaalseks ning ei näinud põhjust liigseks pabistamiseks.

Ilmselt on sellise suhtumise taga mitu põhjendust. Ühelt poolt on noored inimesed valdavalt optimistlikumad, sest nad pole kogenud pettumusi ega näinud nii palju elu pahupoolt. Teisalt hakkas ühiskond muutuma peaaegu samaaegselt sellega, mil nad hakkasid märkama, mis neid ümbritsevas maailmas väljaspool kodu toimub. Seega kasvasid nad koos muutustega ning muutus kui selline sai nende jaoks normaalse elu osaks. Ehkki nad ei juhtinud ühiskondlikke muutusi, mõjutas poliitiline atmosfäär nende endi aktiivsust ja algatusvõimet. Riina jutustas, kuidas nad algatasid klassikaaslastega õpilasi mõnitava geograafiaõpetaja vallandamise, Kaido (snd 1970) kirjeldas komsomoliorganisatsiooni kinnipanekut. Hannes rääkis, kuidas ta koos klassivendadega keeldus käimast perekonnaõpetuse tunnis, sest seal kirjeldatav ei vastanud tema hinnangul kaasaegsele käsitlusele seksuaalõpetusest. Pärast vaidlusi kooli juhtkonnaga saavutasid nad kaaslastega aine sisu muutmise. Niisiis mõjutas muutuste atmosfäär ja nõukogude korra delegitimeerimine neid kriitiliselt suhtuma end ümbritsevasse korda. Seega räägitakse ühelt poolt sellest ajast passiivse agentsuse vormis („sattusime”, „huvitav”, „põnev aeg”), nähes enda rolli pigem kõrvaltvaatajana; teiselt poolt aga räägitakse lugusid, milles kõneleja agentsus on tugev - ent ka siis viidatakse ajastu hõngule ja muutuste algatamisest räägitakse kollektiivses vormis: „aga sihuke kogu aeg oli väike sihuke nagin ja proovile panemine ja õpetajatel ja meil omavahel ja" (Hannes).

„,..see kuidagi juhtub" - kinnine kindlustunne. Optimistliku tulevikuperspektiivi taga võis olla ka seik, et informandid kasvasid üles nõukogude ajal, mida meenutatakse enamasti kui kindlat ja turvatunnet pakkunud ühiskonda (Jõesalu 2005, 2016). Kuigi selle ühiskonna reegleid saab täna vaadelda ebaõiglaste ja sotsiaalsetest suhetest liigselt sõltuvana, oldi siiski nendega tuttav ning see pakkus turvatunnet, mida Henri Vogt (2005) on nimetanud kinniseks kindlustundeks. See tähendab, et ajahorisont oli suletud (kord oli kindel ning arenguperspektiivid limiteeritud), ent struktureeritud. Seega ei teadvustanud ka tollased noored ohte, mis võiksid tööturule siirdumisega kaasneda. Kombineerituna üldise optimistliku suhtumisega, on Taneli (snd 1973) lähenemine üsna tüüpiline: 
Mulle tundus, et ma tahaksin saada diplomaadiks. Ja noh, kui reaalne see oli sel ajal, või... noh, seda ei osanud nagu hinnata. See oli umbes samasugune tahtmine nagu, et tahan saada kosmonaudiks. Noh, võib-olla natuke rohkem. [---]

K: Oskad Sa öelda, mis või kes seda huvi mõjutas?

V: Ei. See oli kuidagi niimoodi noorusest peale. Ma olen nagu see põlvkond, kellele kesktelevisioonist kogu aeg näidati ja rõhutati NATO ohtlikkust ja agressiivset blokki ja-ja... ja tankid sõitsid ja nii edasi. [---]

K: Kas see diplomaadi koht, olid Sa nagu selles väga kindel või oli sellele varuvariante ka? Kui selge see siht oli - töökoht, haridus jne?

V: Ei olnud. Absoluutselt ei olnud. Ei. Ma olin täiesti kindel, et see kuidagi juhtub ja sellepärast ei ole vaja muretseda. Tõesti, see, et ma pean hakkama kunagi, ütleme viie aasta pärast tööle hakkama, et see nagu ei tekitanud minus... Noh, tööpuudus kui selline ei tundunud mulle üldse võimalikuna. Nii, et noh, see probleem, mis praegu, et tööd ei ole noortel... noh, võimatu. Täiesti, et kui Sa oled vähegi peaga tegija, sellist asja ei saa juhtuda.

See intervjuukatke illustreerib kõnekalt ka seda, et paljude jaoks olid nõukogude ajal veedetud lapsepõlve huvid siiski erialavalikul olulised ja seda isegi juhul, kui ideoloogilised kaalutlused ametivaliku taga olid võrreldes lapsepõlveusuga kardinaalselt muutunud. Tanelist diplomaati siiski ei saanud, ent ta töötas intervjueerimise ajal kõrge riigiametnikuna ja ta tööl oli ka rahvusvaheline dimensioon. Kui Tanel teadis, kelleks ta saada tahtis, siis paljudel seda luksust polnud. Taavi (snd 1972) jutustas, et ei osanud oma tulevikku kuidagi ette kujutada ning „lasi elul minna”, kuid ei kartnud muud kui „tüütuid kohustusi”. Ta oli intervjuu hetkel töötu, ent oli „ajanud erinevaid ärisid" ning oli oma tuleviku suhtes optimistlik. Taas - vooluga kaasaminejaid leiab igal ajastul ning selles pole midagi eripärast. Küll aga pole noorel inimesel muutuvas ühiskonnas kuigivõrd aimu, kuhu see vool üleüldse viia võib, sest ühiskonnakord ja selle sümboolsed rollid on muutumises. Seetõttu rääkisid paljud intervjueeritavad lugusid, milles nad sattusid olukordadesse või ametikohtadele, mille olemasolust neil polnud enne seda aimugi või mille tööiseloom töötati välja ajal, mil nad sellele ametikohale asusid. Ehkki sellistel puhkudel sõltus paljugi informandi enda agentsusest, ettevõtlikkusest ja võimest kohanduda ning muutusi algatada, rõhutas jutustamisstiil sageli juhuslikkust ja „sattumist”. Nii rääkis Hannes oma tööleasumisest tänaseks ühe populaarsema ajakirja turundusjuhi kohale:

$\mathrm{K}:$ A kuidas see mõte tuli?

V: Eem... noh minu mõte tuli niimoodi, et tänava peal tuli mulle kodanik vastu, küsis mis teed, ma ütlesin, et noh näed koolis käin ja [---], küsis kas sul aega on... ma ütlesin, et ei oska öelda, sõltub mille jaoks, et näe sihukest asja tahan tegema hakata, ma ütlesin, et muidugi, teeme ära.

$\mathrm{K}$ : Mhm see oli sul ühesõnaga mingisugune tuttav kuskilt varasematest aegadest?

V: Jah... jah ja... siis sai tegema hakatud noh see oli ka sihuke... eks ta vaevaline oli... mäletan neid aegu, kui ma trükikojas ise käisin neid lappamas ja vahelehti sinna panemas nendele kümnele tuhandele ajakirjale ja asjadele... sihuksed suhteliselt vahvad ajad olid. 
Ka siin tasub tähele panna, et Hannes viitab „vahvatele aegadele” ehk millelegi, mis eksisteeris temast sõltumatult ning mille keskele tal oli õnn sattuda. Paljudel olid sarnased kogemused: asuti tööle ettevõttesse või valdkonda, mis oli alles kujunemas, ning ametikohale, mille kohustused erinesid selle ameti ülesannetest nii tänapäeval kui ka nõukogude ajal.

Uued erialad ja juhuslikud eluvalikud. Eelöelduga ei taha ma siiski väita, et kõigi vastanute elutee otsuseid varjutas juhuslikkus või teadmatus. Mitmed informandid unistasid juba lapsepõlves tulevasest ametikohast ning viisid oma eesmärgi täide. Nii soovis Marek (snd 1973) saada loomaarstiks, Kristel (snd 1973) advokaadiks või prokuröriks ning Merje (snd 1977) näitlejaks. Nii ka läks. Paljud unistasid aga ametitest, millest nad olid kuulnud, kuid mida kas nõukogude ühiskonnas polnud või mille töökorraldus oli sel ajal teistsugune. Nii tahtis Meelis saada antropoloogiks, ent sellist õppekava polnud tema keskkooli lõpetades veel ülikoolides avatud. Kristi soovis saada moekunstnikuks, kuid kinnitas, et poleks seda kindlasti kaalunud, kui perspektiiv oleks olnud Tallinna Moemajas ajakirjale Siluett moejooniseid teha.

V: Mmm... Pariisi pidin minema, kuulsaks ja rikkaks saama, aga ma ei tea, kuivõrd tõsiselt ma seda tol hetkelgi võtsin... See oli rohkem naljaga vist... praalitud vist.

K: Et õppima siin ja töötama Pariisis?

V: Jah, mingi sihuke jutt käis küll kogu aeg, ERKI esimestel kursustel eriti. Ma arvan, et ma ei võtnud seda ise ka... väga tõsiselt. Praalimine nagu rohkem.

K: Mida sa tahtsid õppima minna?

V: Oi, moekunsti. Pierre Cardiniks saama.

K: Miks sa moekunsti tahtsid? Millest see tingitud oli?

$\mathrm{V}$ : Ma arvan tagantjärgi, et kas ma seda väga tõsiselt ise võtsin, et sihuke praalimine rohkem. „Ära õienda, tahan kuulsaks ja rikkaks saada” (naer).

Intervjuu ajal oli Meelis kinnisvaramaakler, olles pärast keskkooli õppinud põgusalt teoloogiat ning töötanud muuseumis. Kristi, ehkki moekunstieriala diplom taskus, oli intervjueerimise ajal vabakutseline ajakirjanik ning asutas hiljem oma ettevõtte. Kumbki ei kahetsenud oma unistuste luhtumist. Kristi rääkis unistuse liivajooksmisest huumoriga, ent Janek oli tollase ühiskonna utopistlike tulevikuplaanide suhtes kriitilisem. Ta meenutas, et paljudel oli tunne, et kuna piirid on nüüd lahti, siis tasub vaid välismaale reisida ning saabub läbimurre, viidates näiteks ühe popansambli intervjuule, kes uskus siiralt, et jõuab Inglismaa muusikaedetabelis esimese 20 sekka.

Kui Meelisel oli soov õppida midagi, mille õppekava polnud tema sisseastumisajaks veel avatud, siis nii mõnedki informandid sattusid enda sõnul juhuslikult õppima eriala, mis just nende keskkooli lõpetamise ajal avati (kunstiteadus, rekreatsioon, politoloogia). Teised sattusid õppima erialasid, mille sisu oli pidevas muutumises (informaatika, ärindus), ning tundsid sageli, et on õppejõududest targemad. Mõistagi ei tähendanud see seda, et nad oma erialal kuigi kogenud või targad oleksid olnud (seda ka enda hinnangul), pigem illustreeris see asjaolu, et neil uutel elualadel polnud Eestis parasjagu kedagi, keda saaks tänapäeva mõistes professionaaliks pidada. Seega ei tähendanud asjatundmatus tihti seda, et sel erialal tööd ei leitud. Nii kirjeldas Ave 
(snd 1973) tööintervjuud ametikohale, kus oli nõutud arvutioskus. Kuigi Ave polnud arvutiga varem kokku puutunud, ei heidutanud see teda kandideerimast. Enne vestlusele minekut palus ta oma poiss-sõpra end arvutitundmises veidi harida. Sõber üritaski teda instrueerida masinat kasutama, ent kuna õpetussõnade jagamise hetkel polnud arvutit käepärast, ei saanud Ave kuigivõrd targemaks. Seetõttu ei läinud tal ka õnneks tööandjatele demonstreerida, et ta tegelikult ka arvutitega midagi teha oskab. Ta palgati siiski, sest ta jättis entusiastliku mulje ning talle taheti anda võimalus. Sarnase loo rääkis Hannes, kes pidi töövestlusel lahendama raamatupidamisülesande, milles ta haledalt läbi kukkus, ent palgati sellegipoolest. Sellised tänapäeval koomilisena tunduvad lood näitavad, et tegelikult polnud tööturul professionaale eriti võtta, sest ka ülikoolides polnud õppekavad uuendatud ning kogemustega töökäsi nappis. Nii jutustataksegi neid lugusid peamiselt juhuslikkuse võtmes, jättes enda agentsusele tagasihoidliku rolli.

Usk iseenda võimetesse. Mõistagi erineb agentsuse aste eri jutustustes. Kuulsin ka lugusid, milles informant haaras ise initsiatiivi. Üks sellistest oli Toomas (snd 1975):

No see oli see, et... noh midagi ju pidi tegema, et... Me saime küll aru, et... et nüüd on see õige aeg, et kõik teevad midagi, et... Siis me nagu... siis me nagu... tegime nagu firma ära ja siis olid hästi suured plaanid, mõtlesime, et võib-olla peaks arvuteid hakkama Ameerikast siia nagu importima, arvutitega oli mingi jama, neid ei olnud üldse... Siis me tegime keskkooli kantseleis, trükkisime trükimasinaga sihukse koltunud vene stiilis paberi peale, tegime nagu mingisuguse inglisekeelse kirja ise oma peaga, mis nagu kubises vigadest, sest me nagu ei tahtnud seda inglise keele õpetajale ette näidata, ja siis saatsime nagu selle faksi teel siis à la, noh peaaegu et Bill Gatesile, ma arvan... ja siis... et... meil on siin umbes (naer) väga suurepärased võimalused... teid esindada... Aga noh, sellega siis nagu väga hästi ei läinud ja siis... Vastuseid vist ei tulnud väga...

Ka Toomas jutustas oma lugu läbi huumoriprisma - midagi sellist ei kujutaks ta täna ettegi. Ometi ei olnud ta löödud oma toonaste, koolipoisina tehtud plaanide luhtumisest. Kui ärist Bill Gatesiga asja ei saanud, lõi ta käed hoopis oma kooli direktoriga, kes kurtis talle, et kooli remontimiseks napib raha, sest ehitusfirmade pakkumised on kõik kallimad kui kooli remondieelarve. Ehkki kooli remondiprojekt tähendas seda, et lõpuks pidi Toomas koos sõbraga ise pintslid ja pahtlid haarama ning kasumit ta sellest siiski ei saanud, jätkas ta uute ärivõimaluste otsimist. Peagi saabusid uued väljakutsed ning tänaseks on ta suure ettevõtte omanik ja üsna jõukas. Ent ka see lugu pajatab sellest, et suur roll oli ajastul ja muutuval elukorraldusel. Toomas rõhutas ka ise, et oli „sogane aeg” ja „põhimõtteliselt nagu võisid teha ükskõik mida ning oli vaja ainult pealehakkamist [---] ... et midagi saavutada". Teisisõnu, isiklik initsiatiiv ja agentsus on Toomase jutustuses olulisel kohal, ent see ei toimi ilma viiteta perioodile, mis „kubises pakutavatest võimalustest”.

Sageli räägitigi oma karjäärist kui millestki, mis pigem ,juhtus", kui oli enda algatatud. Üks selline lugu pärineb Karinilt (snd 1976), kes kandideeris esialgu sõbranna kutse peale ülikooliõpingute kõrvalt sekretäriks, ent liikus sealt kiiresti edasi: 
Mina tegelesin Euroopa Liidu asjadega 22-aastaselt, eksole, omamata mingit magistrikraadi. [---] Ma mäletan, kui ma läksin sinna Euroopa Komisjoni, ma pidin käima iga kuu Euroopa Komisjonide koosolekutel... Eestit esindamas. Ja kui ma 22-aastasena sinna kohale lipsasin, siis enamus olid mingid seitsmekümnesed gerondid, mingid professorid, eks ole. Vaatasid mind küll suu ammuli, et kes ma sihuke olen üldse. Ma mäletan väga hästi, sest me jäime nagu hiljaks, esimesele või teisele koosolekule jäime hiljaks, ja siis ma tulin sealt uksest sisse ja nurga peal istus mingi Belgia või Hollandi esindaja. Kui ma niimoodi uksest sisse hakkasin hiilima, siis ta ütles mulle niimoodi, et: „Oi, et nii hea, et nüüd tuuakse kohvi." (naerab) Mina ju punastasin seal, onju. Võtsin oma koti ja kobisin niimoodi, kogu seltskond vaatas niimoodi vaikides, kuidas ma ümber laua otsisin seda Eesti silti ka veel. Kus see kurat on. Prantsatasin sinna Eesti koha peale maha ja siis terve seltskond vaatas mind lihtsalt niimoodi suu lahti. Et no me tegime karjääri küll ja me saime üsna ruttu nagu edasi liikuda aga samas me ei olnud need süsteemide ülesehitajad...

Karini lause, kus ta räägib, et nad polnud süsteemide ülesehitajad, vaid selles kiirelt edasiliikujad, viitab samuti juba eespool mitmeid kordi kirjeldatud paradoksile, mis paljude informantide jutust läbi kumab: oldi nagu kõrvalseisjad, aga ei oldud ka. Räägiti oma karjäärist ja suurest vastutusest, mis juba noores eas tuli erinevatel ametikohtadel võtta. Ka sellest räägiti, kuidas töötati nädalavahetustel, öösiti, selle eest tasu ootamata - sest ind oli suur ja aeg oli põnev. Ent kõigi lugude juures on siiski üheks keskseks tegelaskujuks Pöördeaeg. Karin rääkis ka:

Võib-olla ka see kohutav usk enda võimetesse, tänu sellele, kui me olime perioodil, kus saigi ennast kohutavalt palju proovile panna. [---] Meile anti ikka sihuksed ülesanded, mis olid ilmselgelt meile ülejõu käivad ja kellelegi teisele neid ka anda nagu ei olnud.

Teisisõnu on informantide jutustused agentsuse seisukohalt vastuolulised. Lugusid räägitakse justkui kõrvalseisja positsioonilt, ent teraselt kuulates on loo kangelastel täita väga oluline roll: algatatakse koolisüsteemi muudatusi, asutatakse firmasid, juhitakse osakondi ja nõustatakse poliitikuid. Kõneldakse sogastest, segastest aegadest, milles tulevik oli teadmata, rollimudelid puudusid, ent tagantjärele hinnatakse neid aegu põnevateks, vahvateks ja huvitavateks. Nende aegade kujundamisel ei nähta endal suurt rolli, küll aga näitas see aeg kätte paljud uksed, mida julgelt avati.

\section{Kokkuvõtteks}

Rapuntsli loo võrdluse juurde naastes võiks öelda, et informantide jutustused ei klapi ei Grimmide ega Hollywoodi ekraniseeritud versiooni tonaalsusega. Nad pole ei oma saatusega leppivad vaeslapsed ega röövleid taltsutavad kuningatütred, vaid midagi vahepealset. Oma lugudes on nad küll ise oma õnne sepad, ent kirjeldavad edu pigem süllekukkunud võimaluste ärakasutamisena kui meeleheitliku eduotsinguna, omistades omaenda isiksuseomadusele väiksemat rolli. Miks see tänapäeva edukeskses individualistlikus ühiskonnas nii 
on? Ilmselt on põhjuseid rohkem kui üks ja kõiki neist ei jõua siinkohal lahata, ent peatun alljärgnevalt mõnel võimalikul.

Kindlasti pole minu informantide jutustamise stiil ainukordne ega ainult sellele eagrupile omane. Sellist enda agentsuse taandamist on uurijad täheldanud ka nn võitjate põlvkonna lugudes (snd 1965, vt Grishakova, Kazjulja 2008; Saar, Unt 2010). Ilmselt tuleks siin vaadata, kellele ja millistes tingimustes lugu jutustatakse. Uurijale jutustatakse tõenäoliselt seda, mida arvatakse teda ootavat: mälestusi nii endast kui ka möödunud ajast ja suhetest nende vahel. Mõnes teises situatsioonis aga räägitakse oma agentsus suuremaks. Nii näiteks on tavaline meedias osutada tänaste noorte saamatusele, tuues eeskujuks siirdeaja noorte ettevõtlikkust ja pealehakkamist (Kattel 2013; vt ka Nugin 2015).

Teisalt võib põhjus peituda selles, et suurte muutuste tunnetamise ajal on paratamatult üksikisikul tunne, et kuigi ta võib mõjutada teatud protsesse, on ta siiski millegi suurema osa. Seega isegi juhul, kui inimene astub otsustavalt samme enda või teiste elukäigu parandamiseks või ühiskonnaprotsesside muutmiseks, on ebastabiilsel ajal palju kontrollimatuid muutujaid, mida ei suudeta parimagi tahtmise juures hallata. Mõistagi on neid ka stabiilsetel aegadel, ent nende kontrollimise võimalus või võimatus on enamasti teada ja ühene. Ebastabiilsel ajal aga võivad kindlana tundunud asjaolud muutuda või silmapiirilt kaduda ja vastupidi - kontrollimatud asjaolud muutuda kontrollitavateks. Niisiis võib sarnast jutustamisstiili kohata ka teistel pöördelistel aegadel, nt sõjaaegsete põgenemisteekondade jutustustes, kus ühelt poolt võeti initsiatiiv ja oma saatus enda kätte (ei jäädud ootama repressioone), kuid oma lugusid räägitakse siiski võtmes, milles aeg ja selle iseloom on olulisem protagonist kui indiviid ise (vt Jaago 2016).

Ehkki jutustustes on alati pooltoone rohkem kui sotsiaalteadlaste üldistustes, jätab teatud ajaperioodi kogemus jutustustele selle ajastu pitseri ning samas ajaraamis ja ühise sotsiaalse taustaga inimesed kipuvad rääkima oma kogemustest sarnase mustri järgi. Intervjueeritud eagrupile on omane põimida sotsiaalse keskkonna juhuslikkust, kaootilisust ja kiiret muutumist omaenda eluloo valikute ja agentsusega. Nad rõhutavad kiireid muutusi (range korra vahetumist kaootilisega, kaootilise korra vahetumist stabiilsega) ning individuaalseid initsiatiive kirjeldatakse ümbritseva õhkkonna kontekstis, mis sellist initsiatiivi soosis ja õhutas. Aega kujutatakse sealjuures positiivselt, ehkki märksõnad „kaootilisus”, „ebakindlus”, „sogane” ja „keeruline” pole aprioorselt midagi ihaldusväärset.

Me kõik jutustame vaid valitud peatükke oma elust ning sealjuures mõtleme alati end näidata küljest, kust tahame, et teised meid näeksid. Ühelt poolt eeldab see enda (meie hinnangul positiivseks peetavate) isikuomaduste rõhutamist. Teisalt tuuakse sageli välja aspekte, milles iseenda isiku või selle omaduste roll võib olla pisem, ent mis panustavad sellegipoolest isiku kuvandisse ja loovad sellele sümboolset kapitali (Bourdieu, Wacquant 2005). Seda võiks nimetada ka põlvkondlikuks kapitaliks (Nugin jt 2016; Nugin, Kalmus 2017), st sündimine ja elamine teatud ajahetkel muutub omaette ressursiks ning selle esiletoomine annab inimesele ühiskonnas teatud positsiooni. Seega teatud aegade üleelamine või sel ajal ühiskondlikus elus osalemine annab inimesele lisaväärtust ja teda hinnatakse seetõttu rohkem. Just see võib olla ka peamiseks põhjuseks, miks iseenda agentsust vahel taandatakse ning aja- 
perioodile omistatakse suurem roll: sel perioodil elamine andis inimestele teatava kogemuse ja panustas nende iseloomuomadustesse.

Artikkel on ilmunud institutsionaalse uurimisprojekti IUT3-2 „Kultuurimuutused: tähendusloome teoreetilised väljad ja mehhanismid" raames ja Eesti Teadusfondi uurimisgranti ETF9130 „Inimlik aeg ja põlvkondade eneseteadvus” toetusel.

\section{Kirjandus}

Aarelaid-Tart, Aili 2006. Cultural Trauma and Life Stories. Helsinki: Kikimora.

B a m an, Zygmunt 1998. Life in Fragments: Essays in Postmodern Moralities. Cambridge: Polity Press.

B ourdi eu, Pierre, W a c qu a n t, Loic J. D. 2005. An Invitation to Reflexive Sociology. Cambridge: Polity Press.

Crosten 1999

Funk, Karlo, To ots, Janno, V ahter, Tarmo 1995. Mõtteid valmiva põlvkonna ajudest. - Eesti Ekspress 23. I.

Gennep, Arnold von 1960. The Rites of Passage. London: Routledge and Kegan Paul.

Grishakova, Marina, Kazjulja, Margarita 2008. Social risks and challenges of the post-socialist transition period in Estonia: Analysis of biographical narratives. - Qualitative Sociology Review, kd 4, nr 2, lk 106-125.

Harbus, Antonina 2011. Exposure to life-writing as an impact on autobiographical memory. - Memory Studies, kd 4, nr 2, lk 206-220.

Hin rikus, Rutt 2003. Eesti elulugude kogu ja elulugude uurimise perspektiive. - Võim ja kultuur. Toim Arvo Krikmann, Sirje Olesk. Tartu: Eesti Kirjandusmuuseum, lk 171-213.

Ja g o, Tiiu 2016. Teekonnad ja piirid - elulood piiripoeetika vaatepunktist. Mäetagused, nr 65, lk 95-116.

J õ es a lu, Kirsti 2005. „The right to happiness”: Echoes of Soviet ideology in biographical narratives. - Berliner Ostereuropa Info, nr 23, lk 91-99.

Jõ e s a l u, Kirsti 2016. We were children of a romantic era: Nostalgia and the nonideological everyday through the perspective of a 'Silent Generation'. - Journal of Baltic Studies, kd 47, nr 4, lk 557-577.

Jõ e s a l u, Kirsti, N u g i n, Raili 2012. Reproducing identity through remembering: Cultural texts on the late Soviet period. - Folklore, nr 51, lk 15-48.

Kattel, Rainer 2013. Praegused tudengid tahavad pingutamata võitjate põlvkonda jäljendada. Delfi 22. V. http://arileht.delfi.ee/news/uudised/rainer-kattel-praegused-tudengid-tahavadpingutamata-voitjate-polvkondajaljendada.d?id=66168402

Katu s, Kalev, Pu u r, Allan, Põld m a, Asta 2008. Eesti pere- ja sündimusuuring. Estonian Family and Fertility Survey. Tallinn: Eesti Kõrgkoolidevaheline Demouuringute Keskus.

Koga n, Irene, Unt, Marge 2005. Transition from school to work in transition economies. - European Societies, kd 7, nr 2, lk 219-253.

Kõ r e s a ar, Ene, J õ e s a l u, Kirsti 2016. Post-Soviet memories and 'memory shifts' in Estonia. - Oral History, nr 47, lk 47-58. 
Nugin, Raili 2015. The 1970s: Portrait of a Generation at the Doorstep. (Politics and Society in the Baltic Sea Region 3.) Tartu: Tartu University Press.

Nugin, Raili, Jões alu, Kirsti 2016. Narrating surroundings and suppression: The role of school in Soviet childhood memories. - European Education, kd 48, nr 3, lk 203-219.

$\mathrm{Nu}$ gi n, Raili, Ka lm u s, Veronika 2017 [ilmumas]. Social generations and societal changes. - The Routledge International Handbook of European Social Transformation. Toim Peeter Vihalemm, Anu Masso, Signe Opermann. London: Routledge.

Nugi n, Raili, Kannike, Anu, Raud se p p, Maaris 2016. Introduction: Mapping generations in the Estonian context. - Generations in Estonia: Contemporary Perspectives on Turbulent Times. Toim R. Nugin, A. Kannike, M. Raudsepp. Tartu: Tartu University Press, lk 13-33.

Sa ar, Ellu, Kazjulja, Margarita 2016. Winners and losers in the generation of winners. - Generations in Estonia: Contemporary Perspectives on Turbulent Times. Toim Raili Nugin, Anu Kannike, Maaris Raudsepp. Tartu: Tartu University Press, lk 256-279.

Sa ar, Ellu, Unt, Marge 2008. Selective mobility into self-employment in postsocialist transition: Early birds, later entrants, quitters and shuttles. - International Small Business Journal, kd 26, nr 3, lk 323-349.

S a a r, Ellu, Unt, Marge 2010. Falling high: Structure and agency in agriculture during the transformation. - Journal of Baltic Studies, kd 41, nr 2, lk 215-235.

Sturken, Marita 2008. Memory, consumerism and media: Reflections on the emergence of the field. - Memory Studies, kd 1, nr 1, lk 73-78.

T o o m s e, Mari 2004. Koolist tööle: millistelt positsioonidelt alustavad noored oma tööteed. - Noorte siirdumine tööturule: probleemid, vastuolud, kitsaskohad. Toim Rein Vöörmann. (TPÜ RASI sotsiaalse stratifikatsiooni osakonna toimetised 1.) Tallinn: TPÜ RASI, lk 12-39.

Turner, Victor W. 1969. The Ritual Process: Structure and Anti-Structure. Chicago: Aldine Publications.

Tw en ge, Jean M. 2006. Generation Me. New York: Free Press.

Vogt, Henri 2005. Between Utopia and Disillusionment. Oxford: Berghahn Books.

Werts c h, James 2002. Voices of Collective Remembering. Cambridge: Cambridge University Press.

\section{Biographies and generational patterns}

Keywords: biographical agency, pivotal time, generation of the 1970s, narrative patterns

The article scrutinises the autobiographical stories told by people born in the 1970s. The chosen group spent their adolescent formative years in the whirlwind of the social changes characteristic of Estonia in the 1990s and they found themselves in high positions at an unusually early age, enjoying upward social mobility. The analysis is based on stories elicited from qualitative interviews (biographical, focus-group and in-depth interviews). Specifically, the analysis focused on how the interviewees saw their own role, or agency, and to what extent they referenced the developments in their lives to the social structural background of the political change in the $1990 \mathrm{~s}$. The article demonstrates that despite the modern popular- 
ity of individual success stories, the informants tend to describe their success as a result of taking advantage of their luck rather than of a desperate hunt for success, thus diminishing their personal role.

There may be several explanations for this phenomenon. A general explanation could be that the key of narration is chosen according to the assumed expectations of the interviewer, thus focusing on the relations between periods of times and life. On the other hand, times of great change may easily make an individual feel only partly responsible. Even if one takes decisive steps to improve one's personal life or the social situation, unstable times involve a lot of uncontrollable variables. True, some variables are present during stable times, but in most cases the degree of control or lack of control is known. In unstable times, however, normal circumstances may change or disappear altogether, while some uncontrollable conditions may become controllable. Hence, a similar style of narration can also be met referring to events of pivotal times, such as wartime escapes. Although stories are usually told with more nuances than the generalisations of social scientists, the experience of a certain historical period will leave an unmistakable imprint on the narratives of the period, while the people who happen to have shared not only the experience but also a common social background tend to follow similar patterns (narrative templates), when speaking about their experience.

The age group under study tends to interweave the haphazard, chaotic and hectic aspects of the social environment with their own choices and agency of the time. They emphasise the high rate of change typical of those times (from a strict order to chaos, from chaos to stability) and personal initiatives are described in the context of the surrounding atmosphere, which encouraged and promoted such initiative. The times are depicted as positive, although such keywords as „chaotic”, „uncertainty”, „turbulent” and „complicated” are not commonly perceived as such. When telling an autobiographical story, one may often mention some aspects where the personal role of the story-teller is less salient, but which nevertheless contribute to the image of the person, thus increasing their symbolic capital. It could even be called generational capital, as far as being born and experiencing life in a certain period has become a resource in its own right and an awareness of this background is conducive to higher social prestige. This may well be the main reason why personal agency is sometimes diminished and a greater importance is given to the time period, as it was likely to have provided its contemporaries with a certain life experience and contributed to their character.

Raili Nugin (b. 1975), PhD, Tallinn University, Centre for Landscape and Culture, Researcher, raili.nugin@tlu.ee 